\title{
Where Do We Stand in the Theory of Finance? A Selective Overview with Reference to Erich Gutenberg*
}

\author{
Jan Pieter Krahnen**
}

March 31, 1998

\begin{abstract}
For the past 20 years, financial markets research has concerned itself with issues related to the evaluation and management of financial securities in efficient capital markets and with issues of management control in incomplete markets. The following selective overview focuses on key aspects of the theory and empirical experience of management control under conditions of asymmetric information. The objective is examine the validity of the recently advanced hypothesis on the myths of corporate control. The present overview is based on Gutenberg's position that there exists a discrete corporate interest, as distinct from and separate from the interests of the shareholders or other stakeholders. In the third volume of Grundlagen der BWL: Die Finanzen, published in 1969, this position of Gutenberg's is coupled with an appeal for a so-called financial equilibrium to be maintained. Not until recently have models grounded in capital market theory been developed which also allow for a firm's management to exercise autonomy vis-à-vis its stakeholders.
\end{abstract}

Keywords: Corporate finance, corporate control, Erich Gutenberg, internal financing JEL classification: B21, G3, L2

* This paper was prepared for the Erich Gutenberg centenary conference on December 12 and 13, 1997 in Cologne. I am very grateful to Horst Albach for proposing the subject of this paper, to Bernd Schauenberg for long hours of discussions and thus for drawing my attention to certain key aspects of Gutenberg's oeuvre and their relevance to corporate control issues. This paper also owes much to the inspiration provided by conversations with Albrecht Dietz, Eva Terberger, Manfred Nitsch, Harry Schmidt, Franklin Allen, Martin Hellwig, and to conference participants in Cologne. Special thanks to Paul Keast for his faithful translation of the original German text. Financial support from CFS Center for Financial Studies at the University of Frankfurt is greatfully acknowledged.

** Professur für Allgemeine BWL, insbes. Kreditwirtschaft und Finanzierung, Fachbereich Wirtschaftswissenschaften, Johann Wolfgang Goethe-Universität Frankfurt, Mertonstraße 17-21, 60054 Frankfurt (Main), Germany, Tel. +49-69 798-22568 and Institut für Kapitalmarktforschung - Center for Financial Studies, Taunusanlage 6, 60329 Frankfurt (Main), Germany, Tel. +49-69 242 941-10, E-Mail: krahnen@wiwi.uni-frankfurt.de 


\section{Introduction}

Describing the current state of the theory of finance is no easy task. A field of study which, at the time when Gutenberg's Einführung in die Betriebswirtschaftslehre appeared, i.e. 1958, seemed largely descriptive and self-contained, has since undergone a turbulent and rapid development. As it has evolved, increasing use of microeconomic models and approaches has led to an understanding of the subject as one whose main purpose is to provide explanations, while the emphasis placed by classical business economics on description and recommendations for corporate design and management solutions has been relegated to the background. Erich Gutenberg's comprehensive analysis of corporate finance in the third volume of his Grundlagen appeared in 1968; while it places a new accent on numerous aspects of the subject matter, the general tenor is firmly rooted in the classic understanding of what business economics (or business administration - I use these terms interchangeably) is basically about.

There can scarcely be a domain of business economics that would claim to owe less to the tradition of Erich Gutenberg than the modern theory of finance. Yet in the present essay I would like to question this general preconception. I shall be demonstrating that current research in certain areas of finance has reached a point where it comes very close to what I consider the Gutenbergian view of an enterprise as something with autonomous interests.

For this reason, it would seem useful to preface my selective overview with a discussion of Gutenberg's ideas themselves. The intention will be to elaborate a number of fundamental differences and some - to my mind, at least - remarkable parallels between Gutenberg and current research in the area of finance. The following sections focus on two current and, in my view, crucial questions of finance, namely the building of long-term financial relationships and the design of effective corporate governance structures that enable owners to exercise control, i.e. to monitor the activities of managers.

What I am not attempting to do is to provide a comprehensive overview of investment and the theory of finance in general. For one thing, several comprehensive surveys of this kind have recently appeared (Franke 1993, Brennan 1995, Shanken/Smith 1996), so that a further attempt could hardly be expected to contribute anything new. For another, given the abundance of issues addressed and methods currently being pursued under the heading „Finance“, a complete overview would seem (to me) to be more of a hindrance than a help 
in tracing trends in recent research. My selection is a reflection of my main interests; and hopefully it will also make it easier to draw the connection to Erich Gutenberg, which is what concerns us here.

Viewed from a distance, the current research into investment and finance appears to be dealing with a broad, loosely-meshed network of individual topics. Even from afar, it is not difficult to recognise that adjacent knots in this net represent interconnected sets of themes. The sets of themes addressed by the theory of finance are dominated by questions relating to the design of explicit and implicit contractual arrangements between investors and enterprises. In this context, the discussion focuses particularly on individual forms of financing in situations characterised by asymmetric information, as well as on alleviating the resultant incentive problems.

An incomplete list of corporate finance themes includes the determinants of optimal capital structure and optimal dividend policy; the problems associated with specific forms of financing, in particular debt and equity capital under asymmetric information; but also the characteristics of various forms of internal finance; and in addition, the role of mechanisms designed to mitigate the incentive problems that have been identified: monitoring, bonding, self-selection and screening.

A second major area of study is investment and capital market theory, whose practiceoriented significance is often more impressive than that of corporate finance. This second domain includes portfolio theory, capital market theory and option pricing theory, as well as models designed to explain interest rate structures and exchange rate movements. Studies grounded in investment theory have provided a decisive impetus for corporate financial management and for the development of markets, especially those in which derivative products are traded. As an example, one might cite research into the measurement and control of portfolio risks, where the portfolios in question are the entire assets of a bank (including equity and debt securities, as well as derivatives, in particular swaps and options).

The link between corporate finance- and investment-related themes is the theoretical and empirical analysis of institutions in the financial markets, i.e. the analysis of financial intermediaries such as banks, insurance companies and unit trusts (mutual funds). The list could also be extended to include stock exchanges. There exist today, grouped under the 
heading „market microstructures“, independent programmes of research into the optimal characteristics and the informational efficiency of various forms of market organisation, in particular dealer and auction markets.

As a methodology, empirical studies have gained in importance in recent years, and occasionally experimental studies on subjects such as market microstructure are published. The profusion of different fields of study (and the above is by no means a complete list) and their substantial and growing importance within economic research as a whole is underscored not least of all by the fact that between 1990 and 1997 no fewer than five Nobel prizes were awarded to business economists specialising in investment and finance.

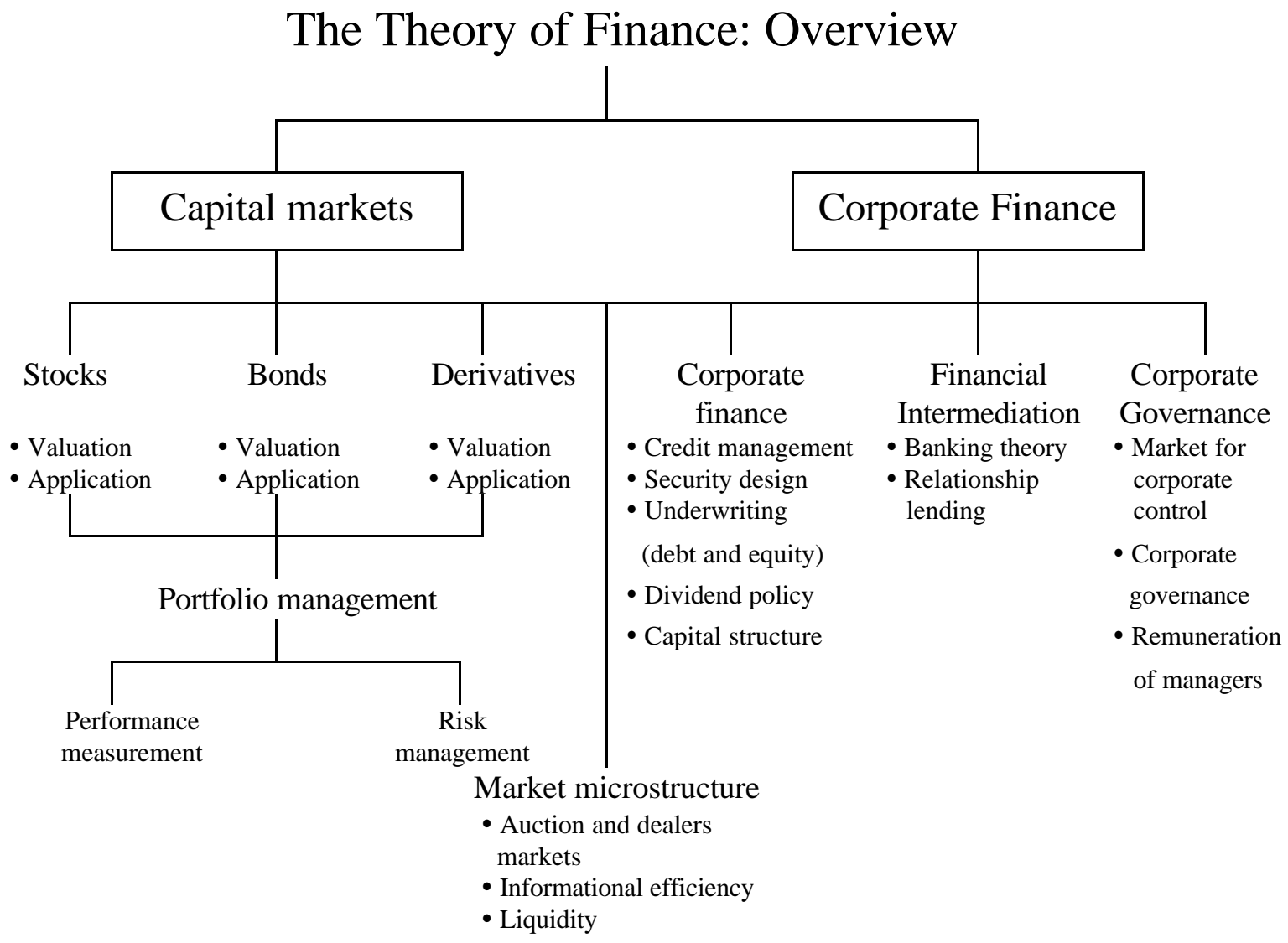

Against this background, the purpose of the present paper is to select a number of „,knots“ in the "network" referred to above, nodal points that fall into the ,theory of finance“ category, and to indicate the links between these nodal points. It is not possible to discuss here the history of the ideas that underpin financial research, and the development of those ideas over the past four decades. Instead I refer the reader to my essay on „financial theory 
between market and institution“. In Krahnen (1993a) the development of financial theory is presented as a series of pendulum swings between a primarily market-oriented and a primarily institution-oriented approach. This duality of market versus institution is also evident in recent writings on market microstructure (Spulber 1996) and banking theory (Bhattacharya/Thakor 1993).

\section{Erich Gutenberg s Finanzen and modern theory of finance}

The outstanding impression left by Gutenberg's Finanzen is that all financing problems are derivative: the protagonist throughout Gutenberg's oeuvre is production - be it in the modelling of production, the optimisation of the production process or the accentuation of product policy. All other functions of a business operation are of secondary importance, being subordinate to production. This allocation of roles is particularly clear in the case of finance. Volume III of the Grundlagen is structured along very similar lines to the first volume, Die Produktion, and also uses largely the same terminology. The main thrust of Vol. III is to link the decision-making problems in the sphere of production to their respective effects in terms of liquidity and finance. The arguments Gutenberg puts forward here consistently move in the same direction: they proceed from the opportunities for production to the financial effects, which, although they can be conceived of as separate (sub-) problems of optimisation, remain nonetheless dependent on the given productionrelated decisions. ${ }^{1}$

Present-day theory of finance takes a radically different approach. It has become a comprehensive theory of decision-making within enterprises, and its models seek to establish links between the claims and behaviour of all the parties involved in the enterprise in terms of Pareto-optimal agreements. Production issues, if considered at all, appear in a highly condensed form, e.g. in the sense of a postulated production function or postulated alternative investment projects, and thus play no more than a peripheral role. To better appreciate the transformation that has taken place in the relative importance the theory of finance attaches to the various elements involved, let us imagine for a moment that a company's value added is represented by a vehicle. In Gutenberg's time, financial managers were perceived as petrol pump attendants who filled up the corporate vehicle

\footnotetext{
${ }^{1}$ An exception to this rule is the treatment of unusual situations, such as bankruptcy or reorganisation, where the financing side is also said to have consequences for the production-related decisions.
} 
with the liquidity it needed to run on. From a present-day viewpoint, financial managers are seen as having traded in their pump attendant's uniform for a chauffeur's cap. Their task is now to direct and control the company's creation of value added and therefore - to retain the vehicle image - they now have their hands on the steering wheel.

When reading Finanzen, three characteristics stand out which, taken together, also underscore the supportive, ancillary role of financial management in a world that is primarily governed by the imperatives of production. ${ }^{2}$

First, optimal corporate financing policy is a function of the firm's capital needs, its capital fund and the co-ordination of these two factors. These three elements also form the subjects of Parts I, II and III respectively of the third volume of Grundlagen der Betriebswirtschaftslehre. Here, the supply of, and demand for capital are developed as two exogenous functions, independent of one another, which are derived primarily from the exigencies of the production process. ${ }^{3}$ Against this background, Part III then deals with the co-ordination of the two in the sense of an elaborate simultaneous planning process which also attempts to capture in precise detail the temporal dimension of the production process. As is customary in models of integrated investment planning, the underlying payment flows of the investment alternatives and financing alternatives are assumed to be independent of one another. In isolating the optimisation problem on the level of the individual enterprise, simultaneous planning models refrain from any explicit attempt to model the lender/investor's rationale, his objectives and his constraints. As a programme for research, this view has consistently been superseded by one which focuses on the endogenous nature of capital needs and the supply of finance (see Weingartner 1977 and Krahnen 1993).

Second, Gutenberg's research programme presents the enterprise as an autonomous unit, i.e. largely independent of the stakeholders (owners, creditors, employees, etc.) which have become such an integral feature of today's discourse. In particular, there is no special orientation towards the interests and goals of any one group, e.g. shareholders (see, for

\footnotetext{
2 The dominance of non-monetary considerations in Gutenberg's works can also be explained with reference to the historical period in which he was writing, a period in which the problems of a war economy and of economic reconstruction played a particularly important role.

${ }^{3}$ Gutenberg had already set forth a tentative version of this interpretation in his review of Polak's (1926) influential survey of the „basic features of finance“, see Gutenberg 1927.
} 
example, Gutenberg 1980, p. $148^{4}$ ). This assumption by Gutenberg presumably coincides with the view taken within large firms even today - despite an increasing tendency to express the enterprise's commitment to maximising shareholder value. In contrast, the dominant view underlying today's theoretical models of contractual relationships is that there are no interests of the enterprise as such, i.e. a co-ordinated set of goals pursued by various actors, as discrete from their own respective individual interests. Generally speaking, the constellation of interests of one group, namely the shareholders, are postulated as the given objective function (of the principal), and an attempt is then made to minimise the degree of deviation from these objectives by optimising the design of the contracts concluded with the agent or agents. ${ }^{5}$

Third, the guiding principle underlying the process of co-ordination between capital needs and the so-called capital fund in Gutenberg's third volume is the need to ensure that a permanent „financial equilibrium“ is maintained. This term implies that the cash flow must at all times be at least equal to the outgoing payments that simultaneously fall due. The notion of a financial equilibrium first appears in Gutenberg's review of Polak's „Grundzüge der Finanzierung mit Rücksicht auf die Kreditdauer“ (see Gutenberg 1927). In the context of simultaneous planning models, the stipulation of a financial equilibrium for any time $\mathrm{t}$ translates into an inequation which compares the cumulative volume of a firm's cash flow up to time $\mathrm{t}$ with the volume of its outgoing payments during the same period. (For details, see Gutenberg 1980, pp. 272-277.) Gutenberg broadens the concept of financial equilibrium to include situations of uncertainty. The term ,financial elasticity“ is used to denote options for adjustment in cases where actual values differ from target values. Financial reserves should be available for such contingencies, he argues (see Gutenberg 1980, Chapter 14).

\footnotetext{
${ }^{4}$ Here he writes, for example: ,...es lassen sich ohne Zweifel Fälle aufweisen, in denen das Verhalten von Großaktionären und Inhabern von Einzelfirmen und Personengesellschaften gegen das Interesse des Unternehmens, seine Sicherheit und seine Entwicklung verstoßen hat, [...instances can undoubtedly be identified in which the behaviour of major shareholders and owners of sole proprietorships and unincorporated firms has run counter to the interests of the firm, its security and its development] (emphasis added).

5 Although the shareholders' objectives are normally assumed to dominate (because they are regarded as residual claimants), there is no logical imperative that necessarily precludes the dominance of the objectives of any other group of actors, e.g. those of managers (employees). For a legal perspective on this question, see Schmidt/Spindler 1997; see also the explanation of the management function (labelled „dispositiver Faktor“ by Gutenberg), i.e. the people who perform management functions, e.g. regarding an optimal design of a company’s input-output relationship in Albach 1989, pp. 67-72.
} 
The basic situation assumed by Gutenberg - that of the enterprise as an entity with autonomous interests was probably shaped to some degree by his own experiences in a mechanical engineering firm when, in the 1920s, he was being prepared to assume management responsibility for his father's agricultural machinery factory. ${ }^{6}$ Gutenberg's notion of the (autonomous) interests of the firm was thus not naive, as is evidenced by his discussion of conflicting interests between management and owners (Gutenberg 1951, pp. $381-383){ }^{7}$

From the standpoint of today's dominant theory of the firm, the notion of the enterprise as an entity with autonomous interests appears not merely to be a relic from a bygone age, but is indeed a veritable counterpoint to a stakeholder-oriented model of the firm. In the stakeholder model, corporate goals can be derived from the constellations of persons and groups that are part of or connected with the company. Ultimately, owners - or shareholders - make their impression on corporate decisions by virtue of their role as residual claimants. The interests of all the other parties, in particular those of the firm's employees and creditors, enter into the optimisation programme in the form of constraints. Viewed from this angel, the drive for financial equilibrium appears to be more of an incentive problem than a useful constraint for the firm's optimisation programme. This reassessment of the financial equilibrium is a consequence of an orientation towards the market value of the firm, which has become the generally accepted practice today. Maximising market value may be accompanied by financial equilibrium, but it does not have to be. In particular, when a corporate strategy geared towards maximising market value leads to (partial) liquidation, the equilibrium condition can and should be broken in the interests of market value maximisation. If, nonetheless, priority is accorded to financial equilibrium, the outcome is a variation of the overinvestment problem described in the annex. Thus, today financial equilibrium is not ,economically correct“, either as a goal or as a constraint (for a more detailed discussion of this point, see Wagner 1997).

For the past 20 years, the theory of finance has been dominated by principal-agent models aimed at optimising the realisation of owners' interests in a situation characterised by

\footnotetext{
${ }^{6}$ He never actually assumed this entrepreneurial role because the firm was liquidated in 1925, enabling Gutenberg to continue his academic career. See Albach 1989, Chapter 1.

${ }^{7}$ I thank Albrecht Dietz for drawing my attention to this element of Gutenberg's work. The incentiveoriented view of the firm was, however, not systematically integrated into the rest of his writings, notably in the field of finance.
} 
asymmetric information or incomplete contracts. The notion of an enterprise with autonomous interests of its own is alien to these models. Nonetheless, the principal-agent models allow for conflicts of interest between owners and management, e.g. over the efficient liquidation of the firm's assets. In the more recent incomplete contract models, the interests of management are oriented (at least in part) towards the so-called private benefits of control, a term which refers to the additional benefits derived from expanding the resources controlled by the management. These benefits continue to accrue even when the firm's capital base has been expanded beyond its optimal level. And under such circumstances, unrestrained management decisions can lead to, for example, inefficient liquidation decisions. Or, conversely, units of the company that earn a below-market return may be retained even though they reduce shareholder value. This occurs because the expansion of the capital base, which promises to increase their private benefits, makes inefficient investments appear attractive in the eyes of the management.

In this situation, an optimal financing structure can force the management to take liquidation decisions that are optimal from the point of view of the shareholders. For example, in the model devised by Hart (1995, Chapter 6), imposing the condition of a sufficiently high level of debt ensures that control shifts to the creditors in states of the world in which there is a danger of an inefficient perpetuation of the firm by the management.

The theoretical and empirical literature largely tends to view financing agreements from the point of view of management control (the control paradigm). The design of individual contracts or of a portfolio of such contracts (capital structure) serves to overcome the divergence of goals between investors and management in a cost efficient manner. I would like to take the next few pages to sketch a number of developments in the theory of finance which call the control paradigm into question. The situations analysed include some in which shielding the firm to a certain degree against direct, market value-induced intervention by the shareholders proves to be advantageous. In my view, they reveal tendencies towards an approach which postulates the existence of a firm's autonomous interest in securing its own survival. And I interpret this as evidence of a shift towards the notion of financial equilibrium as a goal to be pursued by an enterprise. In contrast to Gutenberg's concept, however, here it is compatible with the superordinate idea of market value maximisation - and is therefore a tenable argument even when applied to a competitive market environment. 
Finally, it should be pointed out that the three characteristics of Gutenbergian financial theory referred to here - the exogenous nature of the supply of, and demand for capital; the autonomous nature of the interests of the firm; concentration on financial equilibrium - are connected to one another. From a present-day standpoint, they are three features of a corporate management that, for one thing, acts under highly competitive conditions, for another, takes decisions on a basis largely detached from the interests of the present shareholders, and that, finally, takes account of a long-term survival interest as a strict constraint on its investment decisions.

\section{Control as an issue for the theory of finance}

The purpose of this section is to present some recent ideas on management control exercised via financial instruments. The underlying intuition is based on a recently published study by Martin Hellwig on corporate finance (see Hellwig 1997). Three ,channels“ of control are referred to, corresponding to the classic division of financing into equity capital and debt capital (as the two forms of external finance) and internal finance.

\subsection{The market for equity capital}

In the 1980s and early 90s, the notion of corporate control via the market for company shares was the subject of intensive theoretical and empirical investigation. Scepticism regarding the efficiency of a market for corporate control, which was expressed in the early works on the subject by Grossman/Hart 1980 and Stiglitz 1972, was countered by overwhelming evidence of increased market value realised through, for example, hostile take-overs (see Jensen/Ruback 1983). Later studies argue that an increase in the market value of stocks may be the result of a redistribution at the expense of unprotected stakeholders (especially employees) (Shleifer/Summers 1988). It is also claimed that the effectiveness of the market for corporate control is significantly impaired by countervailing activities entrenched corporate administrations which have been able to set up protective devices (,poison pills“) to make take-overs more difficult (see also Jensen 1991).

In the theoretical literature Harris/Raviv (1988) and Grossman/Hart (1988) examine the conditions under which the market for corporate control functions, a market which is particularly likely to be activated by induced changes of management. In a model of incomplete contracts with private benefits of control for management, the authors show that widely dispersed share ownership creates optimal incentives for a take-over if, in order to 
acquire a majority of the voting shares, it is also necessary to buy up the majority of payment flows. The condition of optimality derived from this model corresponds to a corporate governance structure in which each share certificate entitles the holder to precisely one vote (,one share-one vote“).

The optimal control structure of a firm is different from this if the private benefits of control for some shareholders are very large. This would conceivably be the case in a family business, for example. Here, Grossman/Hart's 1988 analysis predicts that second-class shares with limited voting rights will be issued. This practice, as manifested in the issue of non-voting preferential shares, is quite common in a number of European countries, though not in the United States. For Italy it is possible to demonstrate a statistically significant correlation between the size of the price discount for non-voting shares and the percentage of voting shares in the hands of a single person or a single family (Zingales 1994). This can be interpreted as an indication that corporate control via the market for equity capital is not very effective.

On the whole it would appear that the market for equity capital can only temporarily be an effective instrument of corporate control, and only in a small number of countries (Hellwig 1997).

\subsection{Long-term credit relationships and corporate control}

\section{The significance of relationship lending in the theory}

Relationships (between companies and their regular banks or „house banks“) are a key concern of contemporary research, both theoretical and empirical, because they allow one to demonstrate with particular clarity the market-versus-institution duality (Allen/Gale 1995, Rajan 1996, Holmström/Tirole 1996). Let us briefly examine why this is so. Even from the most cursory appraisal of external corporate finance it is immediately apparent that debt capital can be provided both via markets and via intermediaries. Debt capital is supplied via markets in the form of bonds, whereas debt capital via intermediaries typically takes the form of bank loans. Many observers, particularly those who focus on the AngloSaxon capital markets, have noted that market-traded bonds have been gaining ground recently, while bank-intermediated credit finance has experienced a corresponding decline (Hellwig 1991, Edwards/Mishkin 1995, Domanski 1997, Berlin/Mester 1997). 
The question of a possible „Obsolescence of Commercial Banking“ (Miller 1997) is an obvious one to ask. That intermediaries are likely to be pushed back still further is indicated, among other things, by the positive returns to scale that are expected to come from centralised credit assessment by rating agencies, as a substitute for decentralised assessment by several banks. Furthermore, market-traded bonds permit a superior risk allocation, and, thanks to daily valuation and realisation on the exchanges, they offer a high degree of liquidity and rapid information revelation.

In this context, the theoretical literature has devoted particular attention to the opportunities and risks associated with the renegotiation of multi-period loan agreements. Incentivecompatible contracts are determined which on the one hand prevent renegotiation (e.g. Stiglitz/Weiss 1983), or, on the other hand, intentionally provide for renegotiation as a possible means of sequential incentive creation (e.g. Hart/Moore 1988). When comparing market-oriented long-term bond financing with intermediary-oriented long-term credit relationships, the literature discusses two arguments in particular.

Dewatripont/Maskin 1995 see the advantages of bond financing in the certainty of being able to avoid renegotiation. The argument runs as follows: if debt finance is provided not via the market but by a person or an intermediary, and if the borrowing enterprise in question runs into difficulties that prevent it from repaying the credit on schedule, the lender is caught in a classic „lock-in“ situation. The credit it disbursed now constitutes sunk costs, while the borrower can renegotiate. It is now in the lender's own interests to agree to, say, an additional loan, a remission of interest or a repayment deferral if by doing so it makes repayment at some later date more likely. The inefficiency of this process is derived from the fact that when the loan is first issued the borrower already knows it can renegotiate if it encounters problems later, and thus may from the very beginning have an incentive to invest suboptimally. A single lender would find it difficult to signal credibly at the start of such a relationship that it would not be willing to renegotiate. In contrast, in the case of a bond traded in the market with a large number of anonymous bond-holders there is virtually no chance of successful renegotiation. Even if the holders of the bond were known, the freerider problem creates an incentive for every bond-holder to abstain from the renegotiations and thereby uphold the full value of his or her claim.

The counterposition emphasises the freedom of action under uncertainty that arises as a consequence of renegotiation. Supporters of this argument apply it in particular to the special nature of the financing relationship between lenders and their clients, and stress the 
positive aspects of the opportunity to renegotiate in this context (see Breuer 1994, Berlin 1996, Rajan 1996). In relationship lending there is a special bond of trust which may have evolved through the lender's many years of dealings with this contractual partner, as well as through the lender's being especially well informed about the qualities of the borrower and its projects. In any case, so the hypothesis runs, superior information creates a basis for trust which can, in effect, bind the borrower to the lender in a reversal of the lock-in situation described above.

This is so because the cancellation of a loan could also signal to uninformed competing lenders that this was a borrower with a bad project, as a consequence of which they would impose correspondingly strict terms on any loan they might grant to that particular firm, or indeed the firm may not receive a loan at all. In this situation the relationship bank or ,house bank" can offer an implicit insurance without having to fear that the borrower will try to exploit its position. This insurance may consist in the bank's willingness to extend the term of the loan if the borrower runs into acute liquidity problems, or to waive interest and principal payments without making use of its right to sue for bankruptcy. In return for this service, the borrower pays an insurance premium which may take the form of a larger margin (to be paid later) or large commission fees on additional (future) business (crossselling). In terms of pricing policy, this is an intra- or intertemporal cross subsidy. Under these conditions, financing through an intermediary represents a means of smoothing the supply of liquidity to firms. In order to be able to serve as a buffer in this respect, banks must themselves be protected against shocks. In this connection, Berlin/Mester (1997) emphasise the role of interest inelastic core deposits (i.e. savings deposits subject to statutory withdrawal notice).

It is worth dwelling for a moment on the question of why the smoothing effect on payment flows that is associated with relationship finance should be efficient. One reason is that it allows observers to distinguish between transitory and permanent idiosyncratic - i.e. firmspecific - shocks. Relationship lenders, which are comparatively well informed, are in a position to identify transitory shocks more reliably than uninformed sources of capital (e.g. investors in the bond market), who will not be able to distinguish between transitory and permanent problems and therefore will not be able to adjust their lending terms and conditions (interest rate, collateral, volume) accordingly.

This situation, taking idiosyncratic shocks into account, provides a starting point for a positive theory of financial relationships. At this stage it should be noted that liquidity 
buffers cannot always be made available on the basis of public information, i.e. information to which the market has access, and that therefore the provision of insurance by an intermediary based on private information can be of value.

\section{Empirical significance of relationship lending}

Can the existence of this insurance function in the context of financial relationships be demonstrated empirically? Under which conditions can it evolve in competitive markets? The answer to these questions follows directly on from the question of the „Obsolescence of Commercial Banking“ referred to earlier. Insofar as, under competitive conditions, credit relationships evolve in which the borrower is locked in and profit expectations are positive, relationship banks will not (and cannot) be squeezed out of the market.

In the past, systematic empirical research into the question of credit finance has failed mainly because of a lack of available data. In the meantime, data sets of this type exist for a number of countries. In one of the first event studies on the significance of credit finance, James (1987) finds in the U.S. stock market a positive risk-adjusted excess return on the shares of firms that announce the granting of a bank loan. Follow-up research by Lummer/McConnell (1989) and James/Wier (1990) demonstrates that a significant wealth effect occurs when the extension of an existing credit relationship is announced, but not when a first-time loan is granted.

The authors interpret this result as an indication of the significance of relationship lending. According to this view, a decision to extend a credit relationship is based on information that the bank has been able to acquire during the course of the preceding business relationship. A decision to extend can therefore be interpreted as a decision backed by information which is superior and private, i.e. the details are not known to the market. Under these circumstances, an announcement of the extension of a credit relationship can be regarded by the market as a positive signal of quality (in the sense of a low default probability), which causes the value of that firm's equity to rise. The difference between an extension and the granting of an initial loan lies in the fact that a first-time loan is not based on private information, since even the credit assessment of a bank can, as a rule, only draw on public information.

A series of studies on the United States have been based on extensive new data sets on the terms and conditions of loans issued to small and medium-sized enterprises. Petersen/Rajan (1994) apply the results of a theoretical study by Diamond (1991) on the acquisition of 
reputation in bond markets, taking the length of an uninterrupted business relationship between bank and firm and the diversity of the business relationship with the lender (crossselling) as proxies for the strength of a relationship.

Using data on the most expensive form of finance in each case, namely trade credit, the authors find that the relationship variables have a significant impact. They interpret this finding as corroboration of the hypothesis on credit rationing advanced by Stiglitz/Weiss (1981).

In contrast, they find no correlation between their relationship proxy and the interest margin agreed upon in the credit contract. In a parallel study using the same data set but this time applied to lines of credit, Berger/Udell (1995) find that borrowers with longer contractual relationships pay lower interest margins and have to furnish less collateral. However, both of these studies leave open the question of whether the observations are indeed an effect of relationship lending, or whether they merely reflect a learning effect based on long-standing customer relationships which applies equally to normal banking relationships and to „house bank" relationships, similar to the experience rating with which we are familiar from the insurance business.

A recently concluded investigation allows us to differentiate for the first time between house-bank and normal banking relationships based on a data set for the Federal Republic of Germany (Elsas/Krahnen 1998). This involves the self-assessment of credit department managers with regard to the „relationship“ quality of individual loans chosen at random from their loan portfolios. ${ }^{8}$ One of the insights to emerge from this survey was that the length of the business relationship, which in previous experiments had been used as a discriminatory criterion, is an imprecise proxy for the existence of a „house bank“-type relationship. It turns out that the median length of business relationships between borrower and bank is indeed about the same for house bank relationships as for normal banking relationships, the difference being not statistically significant. Thus the duration of a credit relationship cannot be a precise discriminatory criterion for relationship lending.

The hypothesis was tested which claims that where there is a perceptible change in the client's credit standing the house bank assumes an insurance function (Rajan 1996) insofar as it does not reduce the absolute volume of the finance it provides, and in fact increases it

\footnotetext{
8 The survey was conducted in early 1997 at five German banks: Bayrische Vereinsbank, DG-Bank, Deutsche Bank, Dresdner Bank, West LB. On the data set used, see Elsas et al. (1998).
} 
in relative terms. In contrast, normal banks in the same situation will, according to this hypothesis, reduce their financial commitments in both absolute and relative terms. A panel regression for the German data set confirms the hypothesis that house banks perform an implicit insurance function and finds no such characteristics for normal banks. For the purposes of this investigation, changes in the banks' internal rating of its customers was taken as an indicator of a perceptible change of credit standing.

However, this does not answer the question of how the insurance service provided by a house bank is paid for. As yet, no conclusive data are available that would enable us to verify the hypothesis of intra- or intertemporal cross subsidies. However, there is also reason to doubt whether the internal customer costing data needed for earnings-oriented relationship management could be made available.

Empirical interest in the structure of credit relationships has been growing recently, and it is to this area of research that we must turn in order to obtain empirical evidence of the existence of an economic value of relationship lending. Theorists have offered a large number of possible explanations, most of which are derived essentially from the private information capital referred to at the beginning of this section, which the lender accumulates during its long-lasting relationship with its client and which, in terms of content, extends beyond the stock of public information which accrues in the context of normal banking relationships.

\section{Modelling long-term debt contracts}

Although empirical inquiry into the existence and significance of relationship lending has only just begun, ${ }^{9}$ the general question of the conditions for the co-existence of long-term finance supplied by intermediaries (private debt) and finance obtained directly in the market (public debt) appears to pose a challenge to the theory of finance. Closely linked to this question is not only the question of a permanent line of separation between direct market relationships and indirect, intermediated relationships, but also the theoretically significant question of the general modelling of long-term contractual relationships. As well as providing an explanation of relationship lending, other possible applications of such models include the more general issue of how reputation is accumulated. These models need to take

\footnotetext{
9 The reader is referred to the conference on „Credit Risk Management and Relationship Banking“ organised recently by the Center for Financial Studies at the University of Frankfurt (Main) and the Salomon Center of Stern School of Business (NYU), where the findings of empirical research into relationship lending in the United States, Norway, Germany and Italy were presented (see also the forthcoming symposium in the 1998 Journal of Banking and Finance).
} 
account of the risks and opportunities created by the fact that the preferences of the participants may change (for opportunistic reasons) over time in the sense of time-consistent behaviour.

Whether the possibility of renegotiation is to be seen as something positive or something negative - as a welfare-reducing risk or as a welfare-enhancing opportunity - is by no means clear a priori, but depends on the design of the model. On first examination one notices that the models differ from one another in terms of their informational assumptions. The modelling tradition that goes back to the principal-agent model (Stiglitz/Weiss 1981, Diamond 1991, Ewert/Wagernhofer 1997: Chapter 10, Kürsten 1997) imposes a limit on the quantity of possible contract designs by assuming permanently asymmetric information between the parties to the contract. Therefore, as a matter of principle, contracts can never be made conditional on factors that are only observable to one of the parties (e.g. investment decisions, labour input), and accordingly renegotiation must be precluded.

In contrast, models aimed at explaining incomplete contracts (Aghion/Bolton 1992, Hart 1995, Dickhut/Hartmann-Wendels 1997) assume that the relevant decision or result variables (returns on investment, labour input) are non-verifiable. As the distribution of information is at the same time symmetrical, these models leave room for renegotiation between the parties to the contract as a potentially useful possibility.

The annex (see below) presents one formulation of each of these two modelling traditions. Both are designed to model the negotiations between a lender (,,bank“) and a borrower (,entrepreneur") in examples that are as simple and as similar as possible. In both formulations, the objective is to compare a long-term contract with a sequence of shortterm contracts.

Although the assumptions on which these two types of model are based differ with respect to information and preferences, the outcome in both cases is the same. The explanation of the superiority of short-term financing in the model with asymmetric information is based on the incentive effect of the right of termination, ${ }^{10}$ combined with the inability of the ownermanager to obtain alternative finance elsewhere. In the model with incomplete contracts the superiority of short-term financing follows from the possibility that control will shift from

\footnotetext{
${ }^{10}$ Indeed, Stiglitz/Weiss (1981) examine a similar case to that addressed by Hart (1995): after all, the effect of the self-financing condition in Stiglitz/Weiss's equation (9c) is not so much that it influences the incentives but rather that it exploits the budget condition. See Krahnen 1987.
} 
the owner-manager to the lender, combined with the ability of the lender itself to manage the firm without loss of efficiency. The results in both modelling traditions are highly sensitive to small variations in the assumptions, in particular regarding the chronological sequence of access to information and opportunities for action (see Sutton 1990 and Schauenberg 1995).

Where I see an important difference between the two types of model is therefore not so much in the results that can be (or are) derived from them, but rather in the hypothetical situations that are typically described. Whereas most models with asymmetric information foreground the conflict between equity and debt capital (with the owner simultaneously performing management functions), in models with incomplete contracts the lenders deal with a management that is seen as an autonomous group of actors, i.e. as distinct from the owners. Although both types of model are perfectly capable of being used to inquire into this issue, in today's theory of finance it is the incomplete-contract models which have a virtual monopoly of the corporate control theme.

\subsection{Internal finance and corporate control}

The market for corporate control is for equity capital what relationship banking is for debt capital. In both cases, the description of the fundamental situation is dominated by the conflict between the goals of the investors and those of the management. In both cases, explicit and implicit institutional precautions in financing contracts are interpreted as means of reconciling these conflicts and the loss of utility associated with their application is derived.

At this point I would like to draw attention to what is perhaps a remarkable fact which for about the last 10 years has caused a growing sense of irritation among observers.

It has been observed in many industrialised countries that internal financing volumes (depreciation, retained earnings, reserves) as a fraction of the sizes of aggregate spending on fixed assets are quite large. External financing volumes (share issues less capital reductions and/or repurchases of shares; bank loans), in contrast, account for only a minor share of fixed asset investments. Thus, for countries like the US, the UK, Italy, Germany or Japan, the vastly dominant role is played by internal finance (see also Taggart 1985, Mayer 1988, Hellwig 1991). Typically, fixed asset spending can be financed entirely with internal funds. To the extent that the aggregates can be applied to individual firms, these 
observations call into question the ability of investors to exercise influence aimed at securing corporate control. For Germany, recent research by Harhoff finds a positive correlation between cash flow and real investment on the corporate level, supporting the view that investment decisions are largely determined by the availability of internally generated funds (see Harhoff 1997).

However, consideration must be given to an objection, the validity of which can only be tested on the basis of more extensive empirical research. It is perfectly conceivable that, while the preponderance of internal finance may well be true on aggregate, there may also be substantial variation between individual firms, especially when one considers that financial investments, which by no means consist solely of liquid portfolio investments, are totally ignored ${ }^{11}$. If this is so, it means that some firms continue to be obliged to obtain additional finance from external sources, in which case the issue of control also remains relevant. Furthermore, even if financing requirements can largely be covered by internal finance, the remainder that cannot be internally financed may then acquire pivotal significance.

This much can be said: in the aggregate, external finance appears to play a quantitatively subordinate role in the mobilisation of investment capital, and therefore we must assume, until otherwise proven, that in a qualitative sense too, external finance can have little impact on corporate investment and financial policy. In the study by Hellwig cited above, given the observations described above, the primary function assigned to the financial system is that of mediating between the members of the corporate sector, whereas the function of mediating between enterprises and investors is seen as being of only secondary importance. Mediation between enterprises implies the transfer from firms with surplus liquidity to those with „surplus“ investment projects (see Hellwig 1997, p. 237).

In this context, doubts concerning the relevance of the control issue apply both to the market for corporate control and to external finance via relationship lending. In the following, the question I would like to focus on is: what is the significance of a high proportion of internal finance - the financial autonomy of the management, so to speak -for a theory of corporate finance?

\footnotetext{
11 This possibility is also discussed in Hellwig 1997, paragraph 49.
} 


\section{Free cash flow or Commitment Two positions on internal finance}

The central theme of the modern theory of finance, that of corporate control, also touches on the way in which internal finance is utilised. Since the contribution by Jensen 1986, the necessity of control over the management of firms has been identified with their presumed inclination to reinvest free cash flow (see also Hart 1995, Chapter 6). In these models, the asymmetric distribution of information between management and investors leads to a hidden-action problem: investors cannot monitor whether funds are utilised in a manner that will maximise the market value of their investment. Jensen defines free cash flow as those funds of a company which, if re-invested in the best available investment projects, would produce a negative capital value. Adherence to the corporate objective of maximising market value implies that such funds should be distributed to the owners in order to be channelled into more attractive investment projects via the capital market. This was an idea already expressed by Gutenberg when he concluded: ,... that high dividend payouts and retransfers of profits from the capital markets to companies lead to fewer unprofitable investments and fewer instances of misdirected capital spending than lower dividend payouts.“(Gutenberg 1980, p. 271, own translation).

This allocation according to the efficiency criteria of the capital market does not occur if the managements of firms not only aim for market value maximisation but are also able to derive additional benefit from, say, the sheer size of the invested capital base. The benefits of this kind of „empire-building“ can manifest themselves in extra-monetary values, such as power and social recognition, but also in monetary values, such as a stabilisation of the cash flow and, concomitantly, greater job security. ${ }^{12}$ Note, incidentally, that the benefits of empire-building correspond to the ,private benefits of control“ I mentioned earlier.

No systematic evidence has yet been found to confirm the existence of a tendency to retain free cash flow (not least of all, because it is virtually impossible for outsiders to observe the capital value of new investment projects), yet there are a number of indirect pointers in this direction. For example, Jensen $(1986,1993)$ refers in his essay to the uneconomic exploratory activity of large oil companies that were able to realise substantial windfall profits in the wake of the oil price shock.

\footnotetext{
${ }^{12}$ This type of cash flow stabilisation in the sense of a diversification of the firm's operations is not in the interests of the shareholders, since the accumulation of securities portfolios is a perfect substitute for it. See, for example, Berger/Ofek 1995, Dennis/Dennis/Sarin 1997.
} 
Jensen's influential free cash flow hypothesis leads to the appeal for more intensive use to be made of the superior allocational qualities of the capital market and accordingly - not just in „mature“ industries - for more cash flow to be distributed to shareholders. If this is done, the management teams of all companies compete for the available capital, making inefficient investment strategies, such as empire-building, more difficult to implement.

However, it is also possible to imagine situations in which the allocation of finance via a capital market is less efficient than quasi-automatic internal financing. This is the case if, for example, an informationally efficient capital market implies a negative externality for the competitive situation in the product market. This is a hidden-information problem; conflicts of interest between management and the capital market are disregarded here.

The claimed externality of the informationally efficient capital market can be illustrated by means of an example (on the following, see Krahnen 1994; see also Yosha 1995). The starting point is the competition between two (or among several) enterprises in the product market. Competition in this market reduces potential earnings to a „normal“ level. Extra profits can only be earned if a supplier, through product innovation, gains a first mover advantage over his competitors which affords him temporary monopolistic scope. Within a certain period, imitation will erode this lead. In this model, therefore, earnings expectations are driven by innovations that the competitors are not expecting. The possibility of realising a first mover advantage in the subsequent period is a precondition for innovative efforts in the preceding period.

Innovations can be placed at risk if the firm is obliged to obtain the necessary finance on an ad hoc basis in the capital market. If the firm has to mobilise external funds, it is forced to disclose information to the capital market. This in turn means that the intention to innovate has to be publicised earlier than planned, which shortens the firm's lead over competitors. In Krahnen (1994) this disclosure of information leads to the total eradication of the lead effect. The only type of finance which can offer protection against premature imitation is one in which the funds are made available quasi-automatically, or at least without the need to declare specific investment plans and thus without disclosure of information.

This condition is satisfied by internal finance through depreciation, reserves and retained earnings, as these forms are governed by rules and are therefore non-informative. Against this background, it would be in the interests of even equity investors to approve of rulegoverned financing with the cash flow of the enterprise, i.e. financing that does not have to 
be explained each time. Internal finance in this case is an instrument for internalising the external effects of an informationally efficient capital market on the competitive situation in the product market. An alternative method of procuring additional investment capital without having to disclose information publicly is to rely on relationship lending (see Bhattacharya/Chiesa 1995).

Another situation in which the temporary provision of liquidity on the basis of private information functions via relationships but not via the market can be constructed for real options. The term real option denotes an investment project which, on account of timedependent valuation under uncertainty, contains an (implicit) option component (see Myers 1977, Ross 1995). A simple example is the value of a deferred investment (option to wait). For every project whose realisation can be postponed there is a possibility of an increase in value relative to what its value would be if it were executed at once, which, given favourable parameter changes, would increase the market value of the project. By way of illustration, consider the capital value of a project with a steady cash flow given a stochastic interest rate structure. Postponing the start of the project until a date in the future has a positive value because there is no risk of loss but there is indeed a chance of a gain (namely, if there is a downward shift in the term structure of interest rates). Furthermore, we can state that the more volatile interest rates are, the greater will be the value of this postponement. Accordingly, the break-even point for a decision to invest immediately must be raised by the value of the option to wait.

Another argument in favour of rule-governed internal finance is offered by Allen/Gale 1997a. Here the desire to strengthen their autonomy vis-à-vis the owners is assumed to be an essential element of the management's motivation. Excessive control on the part of the shareholders ultimately means interference in the day-to-day operations. Internal finance, including the deployment of free cash flow, gives firms the opportunity to grow, which at the same time is a precondition for recruiting good staff. In Allen/Gale's model, the attendant incentive gains outweigh the possible efficiency losses due to the retention of free cash flow.

An explicit modelling of enterprises' decisions to use internal finance taking the existence of alternative sources of finance (capital market and intermediaries) into account has played hardly any role at all in the literature to date, even though this issue is obviously of great empirical significance. 


\section{Summary}

This selective overview of recent developments in the theory of finance began by asserting that relationships are currently the focus of particular interest. Behind this lies the conviction that only a profound understanding of long-term contractual relationships, taking informational and „hold-up“ problems into account such as may arise between an investor and an enterprise, can enable us to draw a distinction between market-mediated and bankintermediated finance. The current issues of concern to theorists of finance focus on the conflicts between equity investors, lenders and management. Whereas earlier studies foregrounded the lenders versus investors conflict (see Krahnen 1991, Kürsten 1997), in the past few years attention has shifted to the conflict between lenders and/or investors on one side and management on the other. This applies not only to investigations into credit relationships but also to the analysis of corporate governance structures and structural problems of the market for corporate control (see, for example, Hart 1995, Laux 1996).

However, there are growing doubts as to the empirical significance of manager-monitoring through systematic activities of banks, the stock markets and corporate governing bodies (shareholders' meetings, supervisory boards). In this context, the observation that the markets for equity and debt capital play such a small role in the financing of fixed asset investments in the leading industrialised countries is just one argument among several. In addition, there are fundamental doubts as to the ability of the aforementioned control institutions to perform that function, be they house banks (Hellwig 1997), be they representatives of shareholders (Jensen 1993, Wenger 1996), or be it the market for corporate control (Grossman/Hart 1980, Shleifer/Vishny 1997). Besides, there are theoretical lines of argument which suggest that efficiency gains may be achieved by creating a domain of management autonomy that lies outside the tight control exercised by outsiders, i.e. owners or creditors. In other words, the proponents of these views regard the possibilities for, and instruments of, internal finance not, or not only as signs of opportunistic behaviour, but as signs of decision-making autonomy in the context of a separation of ownership and control. ${ }^{13}$

\footnotetext{
${ }^{13}$ In the margin one might note here that the original explanation for a separation between ownership and control was that it represented the delegation of decision-making authority to specialised actors who were thus comparatively more efficient than the owners. On this point, see also Schmidt 1997.
} 
The emerging consensus is that the managers of big companies, despite several elements of peer-monitoring, ${ }^{14}$ enjoy a large degree of decision-making autonomy from the instruments of control of all groups of lenders and investors (Hellwig 1997). What does this mean for the theory of finance? For the time being I see two consequences:

First, to date we have acquired no more than rudimentary empirical knowledge about corporate control issues. Although a great many theoretical works have been written on the basis of models with asymmetric information or incomplete contracts, there have been virtually no serious empirical tests of the hypotheses they contain, especially outside the United States. The lack of available data is, in my view, not so much a cause as a manifestation of the almost complete absence of empirical interest in issues raised by the modern theory of finance, at least as far as corporate control is concerned..$^{15}$ It is perfectly conceivable that, while the large proportion of internal finance may well be true on aggregate, there may also be substantial variation between individual firms, especially when one considers that financial investments, which by no means consist solely of liquid portfolio investments, are totally ignored. If this is so, it means that some firms continue to be obliged to obtain additional finance from external sources, in which case the issue of control also remains relevant. Furthermore, even if financing requirements can largely be covered by internal finance, the remainder that cannot be internally financed may then acquire pivotal significance. Not until the appropriate empirical studies have been carried out will it be possible to gauge conclusively the validity of the hypothesis of far-reaching manager autonomy.

Furthermore, not enough empirical research has been carried out into the extent of corporate control through intermediaries, such as is supposed to be typical of bankdominated systems, to substantiate what we think we know about this area (but see Gorton/Schmid 1998). The evidence to support the view that house banks perform insurance functions is an indication that intermediaries may play a significant role in qualitative terms too - yet it is not proof that they perform a control function.

Second, doubts regarding the financial market-related control instruments obviously raise the question: Who really does set the goals in manager-led enterprises? One cannot rule out

\footnotetext{
${ }^{14}$ See Hellwig 1995 for the concept of reciprocal (peer) monitoring, relating to cross-holdings between corporations.

15 This diagnosis does not apply to all those issues and model verifications which relate to the organisation of stock and bond markets and their relative valuations.
} 
the possibility that research programs focusing on shareholders' interests, based on the fundamental structure of the principal-agent model, do not sufficiently sharpen our awareness of the empirical connections. In a recent OLG model ${ }^{16}$ presented by Allen/Gale 1997b, enterprises develop a long-term survival interest by virtue of their potential longlasting existence and the constant renewal process in the management team (managers are hired young, do not become highly productive until they have grown older, and eventually go into retirement; at any given point in time, members of both generations are employed). Thus, the authors paint a picture of an enterprise that perpetuates itself primarily on the basis of internal finance and whose objective function is defined in the context of a multiagent model subject to the approval of a principal (equity investor). The possibility in principle that each generation of management will „cheat“ (appropriate a non-recurrent rent) is suppressed in the OLG model by the simultaneous presence and monitoring activity of the younger generation (which in turn would like to remain part of the firm in the next generation too, this time as older managers, without being punished by the owners). Under these conditions, the resultant management decisions prove to be efficient, even without an active market for corporate control.

The models that predominate in today's theory of finance do not take long-term OLG scenarios of this kind into account - not least because the typical model design is based on a static two-person situation. The existence of a collective management interest surely has significant implications for the corporate control issue - how they might be connected to the valuation of enterprises in the capital market appears to me to be a completely open question at present.

\section{Some thoughts in conclusion}

At this point, the strands of sections 2, 3 and 4 of this essay converge. The „,control puzzle“ at the level of the individual enterprise given a predominance of internal finance is strikingly similar to the basic situation found by Gutenberg and described in his works - a finding which, as Gutenberg himself repeatedly stated, was shaped more by his own observations than by microeconomic theory (see Albach 1989, Chapters 1-3). Of course, this similarity

\footnotetext{
16 Allen/Gale 1997, Chapter 12. „OLG“ stands for OverLapping Generations. Models of this type render it possible to observe the dynamics of developments over long time horizons; each of the actors lives for only a limited number of periods, and during their lifetime they pass through various phases. Typically, there will be phase of employment and a phase of retirement.
} 
does not prove how modern Gutenberg's analysis was - but it does reinforce the previously offered diagnosis of the control puzzle.

The derivation of an autonomous management interest, as demonstrated in exemplary fashion by Allen/Gale 1997b, can nonetheless go hand in hand with the long-term safeguarding of owners' interests. A precondition for this is the (expected) infinite prolongation of the existence of the firm, thereby avoiding the problem of the last period. ${ }^{17}$ This precondition also demands that a supplementary condition be met, namely an arrangement accepted by all of the parties involved which largely corresponds to Gutenberg's notion of financial equilibrium.

Of course, one should not overemphasise this similarity between the Guternbergian postulate and Allen/Gale's result. To avoid misunderstandings, I would also like to point out that the interest in actual corporate decisions and their possible connection with the market valuation of companies and with possible monitoring activities on the part of intermediaries and active (large-scale) shareholders is by no means intended as an argument against taking a shareholder-value orientation. If anything, it is the opposite. Certainly, a normative analysis should take place in an intensive dialogue with observable phenomena, in the sense of continually improved hypothesis tests. So far, this has hardly happened at all especially in Germany; debates on shareholder value therefore often seem to consist of professions of faith, taking place in what one might call a near vacuum.

This observation can also be applied to other areas of financial research. In the Germanspeaking world there is a mismatch between theoretical and empirical research. The only exceptions are in the area of market microstructure, where price discovery in share and bond markets has been a dominant issue for quite some time. The un-empirical orientation of financial studies in Germany is also striking when compared with the corresponding discipline in other countries; to my mind, there is good reason to subject this orientation, and also its manifestation in course content and doctoral training, to a critical review.

For the continuation of financial market research beyond the control vacuum described above, the following scenario is conceivable: Corporate control comprises two components, one continuous, the other discretionary. For the continuous component an autonomous management develops the self-regulating system of peer monitoring, which is in tune with

${ }^{17}$ If a final period were foreseeable, by backward induction the reciprocal control of managers could not function, and indeed, it would already fail to function in the very first period. 
the long-term existential interests of the firm. Here the main role of intermediaries consists in the necessary smoothing of payment flows over time. The control functions performed by banks, even relationship banks, are marginal at best. External intervention, by contrast, remains discretionary, and confined to just a few events in the life of a company. Here intermediaries, who may be in possession of early information, assume in particular the role of market makers (for voting majorities), and thus the role of brokers of control. Capital markets can, under certain circumstances (not given in mainland Europe), take on a similar function by means of tender offers. 


\section{Bibliography}

Aghion, Philipp/Bolton, Patrick (1992): „An incomplete contracts approach to financial contracting“, Review of Economic Studies, Vol. 59, pp. 473-494.

Albach, Horst (Hrsg., 1989): Zur Theorie der Unternehmung, Schriften und Reden von Erich Gutenberg (Aus dem Nachlaß), Springer-Verlag, Berlin/Heidelberg/New York.

Allen, Franklin/Gale, Douglas (1995): „A welfare comparison of intermediaries and financial markets in Germany and the U.S.“, European Economic Review, Vol. 39, pp. 179-209.

Allen, Franklin/Gale, Douglas (1997a): „Financial markets, intermediaries, and intertemporal smoothing“, Journal of Political Economy, Vol. 105, pp. 523-546.

Allen, Franklin/Gale, Douglas (1997b): Comparative Financial Systems: Competition versus Insurance, Mimeo.

Berger, Allen N./Udell, Gregory F. (1995): „Relationship Lending and Lines of Credit in Small Firm Finance“, Journal of Business, Vol. 68, No. 3, pp. 351-381.

Berger, Philip/Ofek, Eli (1995): „Diversification’s effect on firm value“, Journal of Financial Economics, Vol. 37, pp. 39-65.

Berlin, Mitchell (1996): „For Better and For Worse: Three Lending Relationships“, Federal Reserve Bank of Philadelphia Business Review, Nov./Dec. 1996, pp. 3-12.

Berlin, Mitchell/Mester, Loretta J. (1997): „Why is the Banking Sector shrinking? Core deposits and relationship lending“, Working Paper No. 96-18/R, The Wharton School, University of Pennsylvania, April 1997.

Bhattacharya, Sudipto/Chiese, G.: „Proprietary information, financial intermediation, and research incentives,“ Journal of Financial Intermediation, Vol. 3, pp. 328-357.

Bhattacharya, Sudipto/Thakor, Anjan V. (1993): „Contemporary Banking Theory“, Journal of Financial Intermediation, Vol. 3, pp. 2-50.

Boot, Arnoud W. A./Thakor, Anjan V. (1997): „Financial system architecture“, Review of Financial Studies, Vol. 10, pp. 693-733.

Brennan, Michael J. (1995): „Corporate finance over the past 25 years“, Financial Management, Vol. 24, No. 2, Summer 1995, pp. 9-22.

Breuer, Wolfgang (1994): „Finanzintermediation und Wiederverhandlungen“, in: Kredit und Kapital, pp. 291-309.

Dennis, David J./Dennis, Diane K./Sarin, Atulya (1997): „Agency Problems, Equity Ownership, and Corporate Diversification“, Journal of Finance, Vol. 52, pp. 135-160.

Dewatripont, Mathias/Maskin, Eric (1995): „Credit and efficiency in centralized and decentralized economies“, Review of Economic Studies, Vol. 62, pp. 541-55. 
Diamond, Douglas (1984): „Financial intermediation and delegated monitoring“, Review of Economic Studies, Vol. 51, pp. 393-414.

Diamond, Douglas (1991): „Monitoring and reputation: The choice between bank loans and directly placed debt“", Journal of Political Economy, Vol. 99, pp. 689-721.

Dickhut, Stefanie/Hartmann-Wendels, Thomas (1997): „Die Delegation von Kontrollaufgaben an den Aufsichtsrat", Working Paper, RWTH Aachen.

Domanski, Dietrich (1997): „Disintermediationstendenzen im deutschen Finanzsystem und ihre Auswirkungen auf die Rolle der Kreditinstitute - Eine Bewertung aus geldpolitischer Sicht“, in: Gahlen, Bernhard/Hesse, Helmut/Ramser, Hans Jürgen (eds.): Finanzmärkte, Tübingen, Mohr Siebeck, pp. 271-290.

Drukarczyk, Jochen (1993): Theorie und Politik der Finanzierung, 2nd edition, Munich.

Edwards, J.S.S/Mishkin, F.S. (1995): „The Decline of Traditional Banking: Implications for Financial Stability and Regulatory Policy“, Economic Policy Review, Federal Reserve Bank of New York, Vol. 1, No. 2, July, pp. 27-45.

Elsas, Ralf/Krahnen, Jan Pieter (1998): „Is Relationship Lending Special? Evidence from Credit-File Data in Germany“, Working Paper, Institut für Kapitalmarktforschung/ Center for Financial Studies, Frankfurt a.M..

Elsas, Ralf/Henke, Sabine/Machauer, Achim/Rott, Roland/Schenk, Gerald (1998): „Empirical Analysis of Credit Relationships in Small Firms Financing: Sampling Design and Descriptive Statistics“, Working Paper, Instititut für Kapitalmarktforschung/ Center for Financial Studies, Frankfurt a.M..

Ewert, Ralf/Ernst, Christian (1997): „Strategic Management Accounting, Coordination and long-term Cost Structure“, Working Paper, July 1997, Johann Wolfgang GoetheUniversität, Frankfurt a.M..

Ewert, Ralf/Wagenhofer, Alfred (1997): Interne Unternehmensrechnung, Berlin et al.: Springer Verlag.

Fama, Eugene (1991): „Efficient capital markets II“", Journal of Finance, Vol. 46, pp. $1575-1617$.

Franke, Günter (1993): „Neuere Entwicklungen auf dem Gebiet der Finanzmarkttheorie“, in: WiSt, Vol. 8, pp. 389-398.

Gorton, Gary/Schmid, Frank A. (1996): „Universal banking and the performance of German firms“, National Bureau of Economic Research Working Paper 5453, Cambridge (MA).

Gorton, Gary/Schmid, Frank A. (1998): „Corporate governance, ownership dispersion, and efficiency: Empirical evidence from Austrian cooperative banking,“ Journal of Corporate Finance, forthcoming

Grossmann, Sanford/Hart, Oliver (1988): „One share-one vote and the market for corporate control,“ Journal of Financial Economics, Vol. 20, pp. 175-202. 
Grossmann, Sanford/Hart, Oliver/Moore, John (1988): „Incomplete contracts and renegotiation,“"Econometrica, Vol. 56, pp. 755-785.

Grossmann, Sanford/Hart, Oliver (1980): „Takeover bids, the free rider problem, and the theory of the corporation,“ Bell Journal of Economics, Vol. 11, pp. 42-64.

Grossmann, Sanford/Stiglitz, Joseph (1980): „On the impossibility of informationally efficient markets“, American Economic Review, Vol. 70, pp. 393-408.

Gutenberg, Erich (1927): „Die Kreditquellen in der Finanzierung“, in: Zeitschrift für Betriebswirtschaft, Vol. 9, pp. 683-692.

Gutenberg, Erich (1929): „Die Unternehmung als Gegenstand betriebswirtschaftlicher Theorie", Betriebs- und Finanzwissenschaftliche Forschung, Series II, No. 40, BerlinWien, Spaeth\&Linde, pp. 53-63.

Gutenberg, Erich (1937/38): „Finanzierung und Sanierung“, in: Nicklisch, H. (ed.): Handwörterbuch der Betriebswirtschaft, 2nd edition, Stuttgart, C.E. Poeschel Verlag, pp. 1739-1786.

Gutenberg, Erich (1951): Grundlagen der Betriebswirtschaftslehre, Vol. 1: Die Produktion, $1^{\text {st }}$ edition (Enzyklopädie der Rechts- und Staatswissenschaft, Abteilung Staatswissenschaft), Berlin/Heidelberg/New York (Springer).

Gutenberg, Erich (1957): „Betriebswirtschaftslehre als Wissenschaft“, Academic address delivered on 22 May 1957 at the celebrations to mark the founding of the university, reprinted in excerpts in: Zeitschrift für Betriebswirtschaft, Vol. 27, pp. 606-612.

Gutenberg, Erich (1958): Einführung in die Betriebswirstchaftslehre, Wiesbaden, Gabler

Gutenberg, Erich (1959): Untersuchungen über die Investitionsentscheidungen industrieller Unternehmen, Westdeutscher Verlag, Köln, pp. 216-225.

Gutenberg, Erich (1960): „Die gegenwärtige Situation der Betriebswirtschaftslehre“, in: Zeitschrift für handelswissenschaftliche Beiträge, Vol. 12, pp. 118-129.

Gutenberg, Erich (1961): „Die Investitionspolitik industrieller Unternehmungen“, in: Management International, Vol. 1, pp. 31-42.

Gutenberg, Erich (1980): Grundlagen der Betriebswirtschaftslehre, Vol. 3: Die Finanzen, 8th enlarged edition (Enzyklopädie der Rechts- und Staatswissenschaft, Abteilung Staatswissenschaft), Berlin/Heidelberg/New York (Springer).

Harhoff, Dietmar (1997): „Are there Financing Constraints for R\&D and Investment in German Manufacturing Firms“ Annals d Économie et de Statistique, forthcoming.

Harris, Milton/Raviv, Artur (1988): „Corporate Governance: Voting Rights and Majority Rules“, Journal of Financial Economics, Vol. 20, pp. 203-235.

Hart, Oliver (1980): „Takeover bids, the free-rider problem, and the theory of the corporation,“ Bell Journal of Economics, Vol. 11, pp. 42-64. 
Hart, Oliver (1995): Firms, contracts and financial structure, Clarendon Press, Oxford.

Hart/Moore (1988): „Incomplete Contracts and Renegotiations,“ Econometrica, Vol. 20, pp. $755-786$.

Haugen, Robert A. (1996): „Finance from a new perspective“, Financial Management, Vol. 25, No. 1, Spring 1996, pp. 86-97.

Hax, Herbert (1982): „Finanzierungs- und Investitionstheorie“, in: Koch, Helmut (ed.): Neuere Entwicklungen in der Unternehmenstheorie, Erich Gutenberg zum 85. Geburtstag, Wiesbaden, Gabler, pp. 49-68.

Hellwig, Martin (1989): „Asymmetrical Information, financial markets and financial institutions: Where are we currently going?“, European Economic Review, Vol. 33, p. 277.

Hellwig, Martin (1991): „Banking, financial intermediation and corporate finance“, in: Giovannini, Alberto/Mayer, Colin (eds.): European Financial Integration, Cambridge, New York, and Melbourne, Cambridge University Press, pp. 35-63.

Hellwig, Martin (1995): „Comment on Julian Franks and Colin Mayer, 'Ownership and Control'“, in: Siebert, Horst (ed.): Trends in Business Organization: Do Participation and Cooperation Increase Competitiveness?, Tübingen, J.C.B. Mohr (Paul Siebeck), pp. 196200.

Hellwig, Martin (1997): „Unternehmensfinanzierung, Unternehmenskontrolle und Resourcenallokation: Was leistet das Finanzsystem?“, in: Gahlen, Bernhard/Hesse, Helmut/Ramser, Hans Jürgen (eds.): Finanzmärkte, Tübingen, Mohr Siebeck.

Hellwig, Martin/Staub, Markus (1996): „Capital requirement for market risks based on inhouse models - aspects of quality assessment", in: Swiss Journal of Economics and Statistics, Vol. 132 (4/2), pp. 755-776.

Holmström, Bengt R./Tirole, Jean (1996): „Private and public supply of liquidity“, Working Paper No. 5817, National Bureau of Economic Research, November 1996.

James, Christopher (1987): „Some evidence on the uniqueness of bank loans,“ Journal of Financial Economics, Vol. 19, pp. 217-235.

James, Christopher/Wier, Peggy (1990): „Borrowing relationships, intermediation, and the cost of issuing public securities," Journal of Financial Economics, Vol. 28, pp. 149171.

Jensen, Michael (1986): „Agency costs of free cash flow, corporate finance, and takeovers,“ American Economic Review, Vol. 76, pp. 323-29.

Jensen, Michael (1989): „The eclipse of the public corporation,“ Harvard Business Review, Vol. 67, pp. 60-70.

Jensen, Michael C. (1991): „Corporate control and the politics of finance“, Journal of Applied Corporate Finance, Vol. 4, pp. 13-33. 
Jensen, Michael C. (1993): „The modern industrial revolution, exit, and the failure of the internal control system“, Journal of Finance, Vol. 48, pp. 831-880.

Jensen, Michael C./Ruback, R.S. (1983): „The market for corporate control: The scientific evidence“, Journal of Financial Economics, Vol. 11, pp. 5-50.

Krahnen, Jan Pieter (1987): Incentive effects of terminations: A comment on Stiglitz and Weiss, mimeo.

Krahnen, Jan Pieter (1991): Sunk costs und Unternehmensfinanzierung, Wiesbaden, Gabler Verlag.

Krahnen, Jan Pieter (1993): „Investitionsmodelle, integrierte“, in: Wittmann/Waldemar (eds.): Handwörterbuch der Betriebswirtschaft, Stuttgart, Schäffer-Poeschel, pp. 19521964.

Krahnen, Jan Pieter (1993a): „Finanzwirtschaftslehre zwischen Markt und Institution“, Die Betriebswirtschaft, Vol. 53, No. 6, pp. 793-805.

Krahnen, Jan Pieter (1994): „Überlegungen zu einer Theorie der Innenfinanzierung“, in: Gerke, Wolfgang (ed.): Planwirtschaft am Ende - Marktwirtschaft in der Krise?, Stuttgart, Schäffer-Poeschel.

Krahnen, Jan Pieter/Weber, Martin (1997): „Marketmaking in the laboratory: Does competition matter?“, Finance Working Paper Series, No. 4/97, University of Frankfurt.

Kürsten, Wolfgang (1997): „Zur Anreizinkompatibilität von Kreditsicherheiten, oder: Insuffizienz des Stiglitz/Weiss-Modells der Agency-Theorie“, Zeitschrift für betriebswirtschaftliche Forschung, Vol. 49, pp. 819-857.

Laux, Christian (1996): Kapitalstruktur und Verhaltenssteuerung: Finanzierungsverträge als Bindungs- und Anreizinstrumente, Wiesbaden, Gabler.

Lummer, Scott L./McConnel, John J. (1989): „Further evidence on the bank lending process and the capital market response to bank loan agreements,“ Journal of Financial Economics, Vol. 15, pp. 99-122.

Mayer, Colin (1988): „New issues in corporate finance“, European Economic Review, Vol. 32, pp. 1167-1188.

Miller, Geoffrey P. (1997): „On the Obsolescence of Commercial Banking“, Discussion Paper, NY University Law School.

Myers, Stewart (1977): „Determinants of corporate borrowing,“ Journal of Financial Economics, Vol. 5, pp. 147-175.

Myers, S. C./Majluf, N. S. (1984): „Corporate finance and investment decisions when firms have information that investors do not have“, Journal of Financial Economics, Vol. 13, June 1984, pp. 187-222.

Petersen, Mitchell/Rajan, Raghuram (1994): „The benefits of lending relationships: Evidence from small business data“, Journal of Finance, Vol. 49, pp. 3-37. 
Polak, N.J. (1926): Grungzüge der Finanzierung mit Rücksicht auf die Kreditdauer, Berlin, Spaeth\&Linde

Rajan, Raghuram (1992): „Insiders and outsiders: The choice between informed and arm's length debt,“ Journal of Finance, Vol. 47, pp. 1367-1400.

Rajan, Raghuram (1996): „Why Banks Have A Future: An Economic Rationale“, Banca d Italia Temi di discussione del Servizio Studi, No. 280, October 1996.

Ross, Stephen A. (1995): „Uses, Abuses, and Alternatives to the Net-Present-Value Rule“, Financial Management, Vol. 24, No. 3, pp. 96-102.

Schauenberg, Bernd (1995): „Unternehmerfunktionen, Marktprozesse und Spieltheorie“, in: Elschen, Rainer/Siegel, Theodor/Wagner, Franz W. (eds.): Unternehmenstheorie und Besteuerung, Wiesbaden, Gabler Verlag, pp. 515-548.

Schauenberg, Bernd/Schmidt, Reinhard H. (1983): „Vorarbeiten zu einer Theorie der Unternehmung“, in: Kappler, E. (ed.): Rekonstruktion der Betriebswirtschaftslehre als ökonomische Theorie, Spardorf, pp. 247-276.

Shleifer, Andrei/Vishny, Robert W. (1997): „A survey of corporate governance“, Journal of Finance, Vol. 52, pp. 737-783.

Schmid, F.A. (1997): „Eigentümerstruktur, Agency-Kosten und Unternehmenserfolg: Empirische Evidenz für österreichische Genossenschaftsbanken“, Working Paper, The Wharton School, University of Philadelphia.

Schmidt, Reinhard H./Spindler, Gerald (1997): „Shareholder Value zwischen Ökonomie und Recht", in: Wirtschafts- und Medienrecht in der offenen Demokratie, Freundesgabe für Friedrich Kübler zum 65. Geburtstag, pp. 514-555.

Schmidt, Reinhard H./Tyrell, Marcell (1997): „Financial Systems, corporate finance and corporate governance“, European Financial Management, Vol. 3, pp. 333-361.

Schmidt, Reinhard H. (1981): „Grundformen der Finanzierung: Eine Anwendung des neoinstitutionalistischen Ansatzes der Finanzierungstheorie“, Kredit und Kapital, Vol. 14, pp. 186-221.

Schmidt, Reinhard H. (1997): „Erich Gutenberg and the theory of the firm“, paper presented on the occasion of the centenary of Erich Gutenberg's birth on 12 and 13 December 1997 in Cologne.

Shanken, Jay/Smith, Clifford W. (1996): „Implications of capital markets research for corporate finance“, in: Financial Management, Vol. 25, No. 1, Spring 1996, pp. 98-104.

Sharpe, Steven A. (1990): „Asymmetric Information, bank lending and implicit contracts: A stylized model of customer relationship“, Journal of Finance, Vol. 45, pp. 1069-1087. 
Shleifer, Andrei/Summers Lawrence H. (1988): „Breach of trust in hostile takeovers,“ in Alan J. Auerbach (ed.): Corporate takeovers: Causes and consequences, Chicago, Chicago University Press, pp.33-68

Spulber, Daniel F. (1996): „Market microstructure and intermediation“, Journal of Economic Perspectives, Vol. 10, No. 3, Summer 1996, pp. 135-152.

Stiglitz, Joseph E. (1972): „Some aspects of the pure theory of corporate finance: bankruptcies and take-overs“, Bell Journal of Economics, Fall 1972, Vol. 3, No. 2, pp. 458-482.

Stiglitz, Joseph/Weiss, Andrew (1981): „Credit rationing in markets with incomplete information,“ American Economic Review,Vol. 71, pp. 393-410.

Stiglitz, Joseph/Weiss, Andrew (1983): „Incentive effects of terminations: Applications to the credit and labor markets“, American Economic Review, Vol. 73, pp. 912-27.

Summers, L. (1986): „Does the stock market rationally reflect values?“, Journal of Finance, Vol. 41, S 591-601.

Sutton, J. (1990): „Explaining everything, explaining nothing? Game theoretic models in industrial economics“, European Economic Review, Vol. 34, pp. 505-512.

Taggart, Robert (1985): „Secular patterns in the financing of U.S. corporations“, in: Friedman, Benjamin (ed.): Corporate Capital Structure in the United States, Chicago, University of Chicago Press.

von Thadden, E.L. (1995): „Long term contracts, short-term investments, and monitoring“, Review of Economic Studies, Vol. 62, pp. 557-575.

Wagner, Franz W. (1987): „Ausschüttungszwang und Kapitalentzugsrechte als Instrumente marktgelenkter Unternehmenskontrolle?“, in: Schneider, Dieter (ed.): Kapitalmarkt und Finanzierung, Berlin, pp. 409-425.

Wagner, Franz W. (1997): „Shareholder Value: Eine neue Runde im Konflikt zwischen Kapitalmarkt und Unternehmensinteresse“, Betriebswirtschaftliche Forschung und Praxis, pp. $473-498$

Weingartner, H.M. (1977): „Capital rationing: n authors in search of a plot“, Journal of Finance, pp. 1403-1431.

Wenger, Ekkehard (1989): „Allgemeine Betriebswirtschaftslehre und ökonomische Theorie“, in: Kirsch, W/Picot, A. (eds.): Die Betriebswirtschaftslehre im Spannungsfeld zwischen Generalisierung und Spezialisierung, Wiesbaden, pp. 155-181.

Wenger, Ekkehard (1996): „Institutionelle Defizite am deutschen Kapitalmarkt“, mimeo, Universität Würzburg.

Worms, Andreas (1997): „Bankkredite an Unternehmen und ihre Rolle in der geldpolitischen Transmission in Deutschland“, Wirtschaftswissenschaftliche Dissertation, Universität Frankfurt am Main. 
Yosha, Oved (1995): „Information disclosure costs and the choice of financing source“, Journal of Financial Intermediation 4, pp. 3-20.

Zingales, Luigi (1994): „The value of the voting right: A study of the Milan stock exchange“, The Review of Financial Studies, Vol. 7, pp. 125-148.

Zingales, Luigi (1997): „Corporate Governance“, in: The New Palgrave Dictionary of Economics and the Law. 